\title{
PSYCHE
}

VOL. XXXII.

DECEMBER 1925

No. 6

\section{NOTES ON HIPPOBOSCIDÆ.}

1. Lynchia Weyenbergh and Lynchia Speiser are not Congeneric.

By J. Bequaert,

Department of Tropical Medicine, Harvard Medical School.

While attempting to identify a hippoboscid obtained in Brazil, I was struck with the considerable disparity in size between Lynchia penelopes Weyenbergh, the type of the genus Lynchia, and the other species subsequently placed by Speiser in Lynchia. A closer study of the original description of Lynchia brought me to the conclusion that Weyenbergh's species does not fit the generic diagnosis of Lynchia, as drawn up by Speiser and accepted by subsequent investigators.

Briefly stated, Speiser's genus Lynchia is characterized in the first place by the absence of the anterior basal cross-vein $\left(M_{3}\right)$ : "däs Geäder dadurch auffallend und charakteristisch, dass die hintere Basalzelle ganz offen ist, die hintere Querader total fehlt." Such is the case with Olfersia maura Bigot, Olfersia lividicolor Bigot, and other related species. But it is not true of Lynchia penelopes, which, according to Weyenbergh's description, has the second basal cell (M) closed by a cross-vein.

I subjoin a translation of Weyenbergh's original, since it is inaccessible to most students. In order to make the author's meaning quite clear, I have inserted in brackets the names of the veins as used by most modern writers and also the corresponding symbols in the Comstock-Needham system. For the latter, I have accepted Ferris and Cole's interpretation of the hippoboscid wing (1922, Parasitology, XIV, p. 195, fig. 12.) 


\section{Lynchia Weyenbergh}

Lynchia Weyenbergh, 1881, Anales Soc. Cientif. Argentina, XI, p. 195 (monotypic for Lynchia penelopes Weyenbergh.)

"Antennæ gemmiformes elongatæ setosæ, lateribus hipostomatis insertæ. Ocelli nulli. Tarsi unguibus tridentatis. Alæ latæ incumbentes abdomine multo longiores, acuminatæ.

"This genus must be placed between Ornithomyia and Olfersia. Although the antennæ are bud-shaped, they are longer than in Ornithomyia and hairy, especially at the tips, and are inserted very low down. The two compound eyes are very globular and leave between them a wide front; but there are no ocelli, instead of which one finds on the spot where they usually occur a small triangular plate, of a dark color, and somewhat raised. This peculiarity, viz. the lack of ocelli, removes the genus from Ornithomyia and brings it near Olfersia. The tridentate claws, on the other hand, bring it nearer the former and remove it from the latter, which has bidentate claws [the claws are tridentate in Olfersia also.-J. B.] The wings are on the whole similar to those of Ornithomyia and Olfersia, but in the lastnamed genus they are much rounded off at the apex, and they are also quite obtuse in Ornithomyia; while in Lynchia they are much pointed, although being also very long. The head is flat, disciform, as in the genera mentioned, which it also resembles in the mode of articulation with the thorax and in general appearance. The mouth-parts are very short and completely hidden within the short sheath that envelops them. The line or transverse suture, which divides the thorax into two parts, is very distinct in this genus; but the longitudinal line, which in the other genera is furrow-like, is much raised in Lynchia, even forming a linear elevation. On the outer angle of the thorax one sees an ovate spiracle, with several stiff hairs on the anterior margin. The scutellum is very short and broad. The abdomen bears strong spines on the lateral margins of the segments, and long hairs at the apex. The legs are little hairy; one finds only a few stronger hairs about the claws. The veins of the wings are quite characteristic, although showing some similarity to those of Ornithomyia; but the difference is greater than the resem- 
blance. Only three veins run from the articulation to the lower [posterior] margin of the wing. Furthermore, as in Ornithomyia, the system of wing veins is colored in dark in the portion of the wing toward the anterior border and the articulation, as if the hollow veins were filled there with dense matter; while over the remainder of the wing the veins are delicate and transparent. Meigen shows this quite well in his drawings of the genus Ornithomyia (Syst. Beschr., VI, Pl. 64.) In this connection there exists in Lynchia a peculiarity which has arrested my attention: viz. that the discoidal vein [fourth longitudinal; $\mathrm{M}_{1}+_{2}$ ] is always interrupted by a clear and transparent portion, placed a short distance from the forking of the common posterior [sub-stem vein] into the discoidal [fourth longitudinal; $\mathrm{M}_{1}+_{2}$ ] and the true posterior [fifth longitudinal; $\mathrm{M}_{3}+\mathrm{Cu}_{1}$ ]. At first sight one might believe that the vein is actually interrupted in this spot, but in focussing correctly one soon is convinced that the interruption is merely in the substance filling the vein and not in the vein itself. I had at first thought that this was an accidental abnormality, but it now appears to me to be a typical feature. The costal vein [first and second sections of costa] is very short, not extending over one third of the wing, where the subcostal [first longitudinal; $R_{1}$ ] unites with it and then forms about one third more of the anterior margin, extending as far as the point where the radial [second longitudinal; $\mathrm{R}_{2}+_{3}$ ] unites with the subcostal. The mediastinal [auxiliary; Sc] almost touches the subcostal [first longitudinal; $R_{1}$ ] and consequently the space between both is very narrow. The transverso-basal [humeral cross-vein; $h$ ] is, however, not absent, but is placed in an outwardly oblique direction between the costal and the subcostal [first longitudinal; $\mathbf{R}_{\mathbf{1}}$ ], before the point where the subcostal gives origin to the mediastinal [auxiliary; Sc.] The first longitudinal [second longitudinal; $\mathrm{R}_{2}+_{8}$ ] bifurcates into the radial [second longitudinal; $\mathrm{R}_{2}+_{3}$ ] and the cubital [third longitudinal; $\mathrm{R}_{4}+_{5}$ ] very close to its origin. The radial [second longitudinal; $R_{2} t_{3}$ ] runs toward the anterior border, where it continues some distance as if it were the continuation of the subcostal [third section of costa], and soon unites under an acute angle with the cubital [third longitudinal; $\mathrm{R}_{4}+_{5}$, that is to say in the same anterior border; 
this junction takes place at a point about two-thirds of the distance along the anterior border. The margin of the remainder of the wing carries no vein. The second longitudinal or common posterior [sub-stem vein] bifurcates almost immediately beyond its origin, the bifurcation resulting in the discoidal [fourth longitudinal; $\mathrm{M}_{1}+_{2}$ ] and the true posterior [fifth longitudinal; $\mathrm{M}_{3}+$ $\mathrm{Cu}_{1}$.] The first of these runs at first a little toward the hind margin, thence with a bend toward the fore margin, so that the first articular cell [first basal cell; $\mathrm{R}_{2}$ ], lying between the cubital [third longitudinal; $\mathrm{R}_{4}+_{5}$ ] and discoidal [fourth longitudinal; $\mathrm{M}_{1}+_{2}$ ] and closed by the transverso-media [anterior cross-vein; $\mathrm{r}-\mathrm{m}]$, is very angular in its outer portion. After being connected with the cubital [third longitudinal; $R_{4}+_{5}$ ], at a point about two-thirds along the cubital, by means of the transverso-media [anterior cross-vein; r-m] just mentioned, the discoidal [fourth longitudinal; $\mathrm{M}_{1}+_{2}$ ] runs in a gradual curve toward the lower margin of the wing, where it ends in about the fourth of the lower margin. The other branch, the true posterior [fifth longitudinal; $\mathrm{M}_{3}+\mathrm{Cu}_{1}$ ] runs, also with a gentle curve, toward the same border, where it ends about the middle. The transversodiscoidal [anterior basal cross-vein; $\mathrm{M}_{3}$ ] unites it with the discoidal [fourth longitudinal; $\mathrm{M}_{1}{ }_{2}$ ] at the point where that vein forms the above-mentioned bend, thus forming the discoidal cell [second basal cell; M.] There are no transverso-posterior veins [posterior cross-vein; $\mathrm{m}$ and posterior basal cross-vein; $\mathrm{Cu}_{2}$.] The anal vein [sixth longitudinal; An] has a double origin, runs with a strong curve to the hind margin of the wing, and ends at a point three-quarters of the way along the hind margin, as measured from the tip of the wing. The several veins which form together what we call the anterior system, are all crowded near the fore margin of the wing, and this is true also of the discoidal [fourth longitudinal; $\mathrm{M}_{1}+_{2}$ ], so that the cells and spaces between the veins are very long and narrow. Only the three posterior and the axillary cells $\left[\mathrm{R}_{5} ; \mathrm{M}_{2} ; \mathrm{Cu}_{1}+1\right.$ st $\mathrm{A}$; and $\left.2 \mathrm{~d} \mathrm{~A}\right]$ are large and wide. The crowding of the veins near the fore margin of the wing is also observed in Ornithomyia, though not as pronounced as in Lynchia, and consequently the cells mentioned above are not so much lengthened and not as narrow as in Lynchia. Another 
difference with Ornithomyia is the absence of the mediastinal [auxiliary; Sc] in that genus, where it is fused with the subcostal [first longitudinal; $R_{1}$ ] [This is an error, as the auxiliary vein is present in Ornithomyia also.-J. B.] The transverso-basal [humeral cross-vein; h] is more perpendicular in Ornithomyia. It appears that in that genus an incomplete vein starts from the point where the cubital [third longitudinal; $R_{4}+_{5}$ ] ends in the fore margin, and runs with a strong curve toward the tip of the wing, cutting off part of the first posterior cell $\left[R_{5}\right]$, but incompletely, since, as I have said, this rudiment of vein does not reach the margin itself. It also seems that in Ornithomyia the fore margin is bordered by a vein to within a short distance from the tip, a feature not seen in Lynchia [Neither this nor the foregoing feature of the wing exist in Ornithomyia.-J. B.] In addition in Ornithomyia there is a first transverso-posterior vein, which is found at about the level of the transverso-discoidal [anterior basal cross-vein; $\mathrm{M}_{3}$ ], of which it appears the continuation, forming with it a figure resembling $\mathrm{S}$, and it is especially this feature which makes an important difference in that part of the wing, when the two genera are compared [In Ornithomyia the anterior cross-vein and the anterior basal cross-vein are close to each other, whereas in Lynchia they are far apart.-J. B.] In Ornithomyia there seems to be also a second transverso-posterior vein [posterior basal cross-vein; $\mathrm{Cu}_{2}$ ], placed very near the articulation, between the anal [sixth longitudinal; An] and the posterior [fifth longitudinal; $\mathrm{M}_{3}+\mathrm{Cu}_{1}$ ], immediately beyond the bifurcation of the common posterior [sub-stem vein] into discoidal [fourth longitudinal; $\mathrm{M}_{1}+_{2}$ ] and true posterior $\left[\mathrm{Cu}_{2}\right.$ is present in Ornithomyia, absent in Lynchia.-J. B.] As I have said before, these cross-veins are entirely lacking in Lynchia. Tarsi as elsewhere throughout the family; halteres as in Ornithomyia."

Weyenbergh adds that he uses Schiner's orismology of the wing venation, as set forth by van der Wulp (1871), and that the peculiarities of the wing of Ornithomyia, which he introduces for comparison, are taken from Meigen's drawing of that species. This explains some of the erroneous interpretations which I have p ointed out. Weyenbergh failed to notice that the "first trans- 
verso-posterior vein," which he describes in Ornithomyia, is homologous with the "transverso-discoidal" which he found in Lynchia, the second basal cell being merely much lengthened in Ornithomyia. Evidently this has been the source of Speiser's erroneous assumption that the second basal cell was not closed by a cross-vein in Lynchia.

From the above account it appears that Lynchia Weyenbergh is a synonym of either Olfersia Wiedemann (Feronia Leach; Pseudolfersia Coquillett) or Ornithoponus Aldrich (Olfersia of authors, not of Wiedemann.) Although the description is not very explicit with regard to the structure of the head, the statement that there is a small, triangular, somewhat raised plate in the ocellar region, can, in my opinion, only apply to a species of Ornithoponus. I believe that the name Lynchia will eventually be used instead of Ornithoponus. Since the problem will be fully solved only with the rediscovery of the type-species, I deem it worth while to give a translation of the specific description also.

Lynchia penelopes Weyenbergh, 1881, Anales Soc. Cientif. Argentina, XI, p. 199.

"L. sepia-obscura, oculis subfuscis margine orbitali piceo. Antennæ flavescentes extremo obscuro. Frons flavescens. Alæ hyalinæ. Femora anteriora aurata.

"The eyes are of a dark reddish brown color and an orbital, nearly black half-circle incloses them on the frontal portion. These eyes are large and spherical, and show punctiform facets. The antennæ and the front are yellowish and at the top of the occiput one sees a triangular, dark, somewhat raised plate. On the labrum one sees a dark spot. The tip of the first segment of the antennæ also is nearly black. The thorax is of a dark sepia color; the median, raised line is brownish black, and the whole shows a yellowish sheen, somewhat metallic, especially on the metathorax and along the margins of the scutellum, which latter bears hairs along its posterior border. The abdominal segments are of the same color, very dark; and their margins have a yellowish sheen on the articulations. The veins have the same general color, a little grayish, and the wings are very transparent and large. The halteres are dirty white. The claws of the legs 
are black and the tarsal segments dark brown, a little paler in the middle. The femora are flat, yellowish, with the upper margin nearly black, while the flattened sides are yellowish; the tibiæ of the hind legs are entirely dark or dark brown. The femora of the fore legs are golden yellow on the ventral surface. The articulations of the legs are all dark. The ventral surface of the insect is also very shiny and of a dark sepia, metallic color. The labium is pale brown and the genitalia are yellowish. The venter is finely granulose or shagreened a character which is especially evident in the female. The interruption of the discoidal vein [fourth longitudinal; $\mathrm{M}_{1}+_{2}$ ], which I have mentioned before in the generic description, is perhaps but a specific character; yet this peculiarity seems to me to be constant. Spread of the wings, from the tip of one to that of the other, $2.5 \mathrm{~cm}$. Length (including the head, but not the wings), of female, $1 \mathrm{~cm}$.; of male, $8 \mathrm{~mm}$."

Off "Pavo del monte, Yacú, or Charate," Penelope canicollis Wagler, in the Province of Tucuman, Argentina.

This is evidently one of the largest species of the genus and as such must be related to Ornithoponus obliquinervis (Rondani), of Mexico, and O.rufiventris (Bigot), of Brazil.

\section{Pseudolynchia, new name.}

Lynchia Speiser, 1902, Zeitschr. Syst. Hym. Dipt., II, p. 155. Massonat, 1909, Ann. Université Lyon, N. S., I, Sci., Fasc. 28, p. 295. Aldrich, 1923, Insecutor Inscitiæ Menstr., XI, p. 77. Ferris, 1925, Philippine Jl. Sci., XXVII, p. 415 (Not of Weyenbergh, 1881.)

Type by present designation: Olfersia maura Bigot, 1885.

The generic characters have been correctly given by Speiser, Massonat, Aldrich, and Ferris, so there is no need repeating them here. Of the described hippoboscids, the following appear to belong to Pseudolynchia.

\section{Pseudolynchia brunnea (Latreille.)}

Ornithomyia brunnea Latreille, 1811, in Olivier, Encyclop. Method., Insectes, VIII, p. 544 (Carolina; no host.) 
I refer to $P$. brunnea eight specimens from the following localities:

Alamogordo, New Mexico, three females, without host, May 8, 1902. Academy of Natural Sciences, Philadelphia.

Wareham, Massachusetts, two females, off adult male whippoorwill, Antrostomus vociferus Wilson, June 6, 1901 (O. Bangs Coll.) Museum of Comparative Zoology, Cambridge.

Hot Springs, Virginia, three females, off whippoorwill, Antrostomus vociferus Wilson, July, 1897 (Wirt Robinson Coll.) Museum of Comparative Zoology, Cambridge.

I believe that this species has not been properly recognized thus far. Speiser does not appear to have known it. Coquillett determined as brunnea specimens which were sent to him from Ceará, Brazil (see F. Dias da Rocha, 1908, Bol. Museu Rocha, Ceará, I, p. 77), but these Brazilian specimens were P. maura var. lividicolor (Bigot.)

Although closely allied to P. maura (Bigot), P. brunnea is undoubtedly a distinct species. It is of a very dark brown color, often nearly black. It differs from both $P$. maura and the variety lividicolor in its robust build, in the much shorter and broader wings, which are 5 to $5.5 \mathrm{~mm}$. long and $1.8 \mathrm{~mm}$. wide, and in the shape of the head, the front being distinctly longer. The eyes extend farther toward the occiput, their upper margins reaching much beyond the anterior margin of the smooth vertex. The frontal lunule is relatively short; the basal, undivided portion of the clypeus is rather narrow, but long, the apical, diverging arms being not much over twice as long as the basal portion. The dorsum of the thorax is somewhat less hairy than in $P$. maura. The entire anal cell $[\mathrm{Cu}+1$ st $\mathrm{A}]$ is covered with microscopic setulæ, the axillary cell [2d A] being the only bare part of the wing membrane.

The specific name has usually been credited to Olivier, but the article "Ornithomyie" of the Encyclopédie Méthodique was written by Latreille and is signed "(Lat.)"

\section{Pseudolynchia capensis (Bigot.)}

Olfersia capensis Bigot, 1885, Ann. Soc. Ent. France, (6) V, p. 240 ( $\sigma^{\pi}$; Cape of Good Hope; no host.) 
Speiser (1902, Zeitschr. Syst. Hym. Dipt., II, p. 166), who examined Bigot's type, has given a few additional details regarding the coloration of this species, but its structural characters are not known.

I am inclined to believe that all later records of capensis from Somaliland, Natal, and the Canary Islands, really refer to P. maura.

\section{Pseudolynchia exornata (Speiser.)}

Olfersia exornata Speiser, 1900, Ann. Mus. Civ. Genova, XL, p. 562 (Doloc Tolong, western Sumatra; no host.)

This species is extremely close to P. maura, if at all distinct. Speiser (1902, Zeitschr. Syst. Hym. Dipt., II, p. 163) states that maura differs from exornata "durch ein dunkler braune Farbe der Stirn und ganz wesentlich geringere Beborstung des Kopfes."

Speiser has also recorded exornata from the Oasis Merv, in Russian Transcaspia, and from the River Luazomela, Kenya Colony; but in both cases the specimens were probably $P$. maura.

\section{Pseudolynchia garzettae (Rondani.)}

Olfersia garzettoe Rondani, 1879, Bull. Soc. Ent. Italiana, XI, 1879, p. 23 (Insubria, Italy; no host.)

This species has not been properly recognized. Speiser has referred to it a specimen from Bavaria, but gave no details as to how to separate it from its allies.

\section{Pseudolynchia maura (Bigot.)}

Olfersia maura Bigot, 1885, Ann. Soc. Ent. France, (6) V, p. 237 (Algeria; no host.)

This is the common parasite of the domestic pigeon in the tropical and subtropical parts of the Old World: Mediterranean Region, Asia Minor, India, Mauritius, Africa (from Algeria to the Cape), Philippine Islands, and Hawaiian Islands. I have seen two specimens $\left(\% \sigma^{\top}\right)$ from Asmara, Eritrea, kindly sent by Prof. Bezzi. 
From $P$. brunnea, $P$. maura differs in the much longer wings, which are 6.5 to $7.5 \mathrm{~mm}$. long and 2 to $2.4 \mathrm{~mm}$. wide; the front is distinctly shorter, the space between the inner orbits nearly as broad as long, the upper margins of the eyes reaching hardly beyond the anterior margin of the smooth vertex; the frontal lunule is long; the basal, undivided portion of the clypeus is rather broad, but very short, dividing almost at once into the very long, diverging arms; the anal cell $[\mathrm{Cu}+1$ st $\mathrm{A}]$ is covered with setulæ over the anterior half only, the remainder of the cell, as well as the axillary cell, being bare. I have selected $P$. maura (Bigot) as the type of the genus Pseudolynchia, because it is not only widely distributed, but also one of the few species that may be recognized without hesitation. Excellent drawings of $P$. maura have been recently published by Ferris (1925, Philippine Jl. Sci., XXVII, pp. 416-417, figs. 2 and 3.) The short, stout, black setæ on the plantar surface of the middle basitarsus, mentioned by Ferris, are apparently a sexual character. I find them in all my male specimens, also of the var. lividicolor; in the female they are replaced by small, slender setæ.

\section{5a. P. maura var. lividicolor (Bigot.)}

Olfersia lividicolor Bigot, 1885, Ann. Soc. Ent. France, (6) V, p. 238 (Brazil; no host.)

This is the common parasite of domestic pigeons in South and Central America and the West Indies. I have seen it from the following localities:

Cuba, one male, without host (Poey Coll.) Museum of Comparative Zoology, Cambridge.

Barbados, one male, without host, October 16, 1904 (G. S. Evelyn Coll.) Academy of Natural Sciences, Philadelphia.

Puerto Arturo near Tela, Honduras, four specimens ( $q \sigma^{7}$ ), off domestic pigeons (F. M. Root Coll.) These specimens have been recorded as Lynchia maura by Dr. Root (1925, 13th Ann. Rept. United Fruit Co. Med. Dept., (1924), p. 209.)

Manáos, Brazil, one female taken in flight, at the hotel, September 14, 1924 (J. Bequaert Coll.)

After carefully comparing these American specimens with 
the Old World $P$. maura, I am unable to find any structural differences. Since, however, they are distinctly paler than the typical $P$. maura, I regard lividicolor as the Neotropical variety of that species. Bezzi (1909, Broteria, Ser. Zool., VIII, 2, p. 64) and Austen (1921, Bull. Ent. Research, XII, p. 122) regard the South American form as identical with P. maura.

\section{Pseudolynchia rufipes (Macquart.)}

Olfersia rufipes Macquart, 1848, Dipt. Exot., Suppl. III, p. 69 (Reunion; no host.)

The species has not been properly recognized.

\section{Pseudolynchia simillima (Speiser.)}

Lynchia simillima Speiser, 1904, Ann. Mus. Civ. Genova, XLI, p. 337 (Java; no host.)

This was based upon a specimen recorded as "Olfersia spinifera" by van der Wulp (1880, Tijdschr. v. Entom., XXIII, p. 193.) Speiser's description mentions no structural characters to separate it from the allied species.

Of the seven species listed above, only two have been sufficiently characterized thus far. Probably several of the others are mere synonyms.

Lynchia pusilla Speiser (1902, Zeitschr. Syst. Hym. Dipt., II, p. 157; Cuba) is the type of the genus Microlynchia, which differs from Pseudolynchia in the presence of minute ocelli and a differently shaped scutellum. I also regard Olfersia falcinelli Rondani (1879, Bull. Soc. Entom. Italiana, XI, p. 23; Malta) as a Microlynchia. The size is that of $M$. pusilla and the shape of the scutellum is the same. The ocelli were probably overlooked owing to their small size.

ADDENDA.

After the present paper was sent to the printer, I had occasion to examine many additional specimens of Pseudolynchia, from various sources. Since I was, nevertheless, unable to distinguish more than the two species recognized above, I am more 
than ever inclined to doubt the distinctness of some of the others. Some readjustment of names will eventually be necessary.

\section{Pseudolynchia brunnea (Latreille.)}

Specimens at the United States National Museum:

Ames, Iowa, without host; two specimens, which F. Knab (1916, Insecutor Inscitiæ Menstr., IV, p. 3) referred to P. maura.

St. Vincent Island, Florida, off Antrostomus carolinensis (Gmelin) (W. L. McAtee Coll.)

Princeton, Florida, off Antrostomus vociferus (Wilson) (W. Byrd Coll.)

Barro Colorado, Gatun Lake, Panama, off a nighthawk, Chordeiles acutipennis (Boddaert), September 24, 1923 (R. C. Shannon Coll.)

Specimens at the American Museum of Natural History:

Sherborn, Massachusetts, off Antrostomus vociferus (Wilson) (C. W. Johnson Coll.)

St. Augustine, Florida, off chuck-will's-widow, Antrostomus carolinensis (Gmelin) (C. W. Johnson Coll.)

Specimens received from the Entomological Branch of the Department of Agriculture of Canada (through Mr. C. H. Curran):

Low Bush, Lake Abitibi, Ontario, off a nighthawk, Chordeiles virginianus (Gmelin), four specimens (N. K. Bigelow Coll.)

\section{Pseudolynchia maura (Bigot.)}

A study of an extensive series from all parts of the world has now convinced me of the utter futility of separating lividicolor from maura, even as a variety. One finds all transitions between pale-colored and dark specimens. Moreover, I am inclined to believe that $P$. maura was originally an Old World insect, which was introduced by man into the Americas, together with the domestic pigeon.

Unless otherwise stated, the host of the specimens recorded below is in each case the domestic pigeon.

Specimens at the United States National Museum. 
Palermo, Sicily.

Asmara, Eritrea.

Umbeluzi, Lourenzo Marques, Portuguese East Africa, off "Strix flammea" (C. W. Howard Coll.) This specimen was identified as "L. rufipes" in the collection, but I was unable to find that it differed structurally from $P$. maura.

Oahu, Hawaiian Territory (J. F. Illingworth Coll.)

Kawailoa, Oahu, H. T. (H. T. Osborn Coll.)

Philippine Islands (C. S. Banks Coll.)

Savannah, Georgia (W. Duncan Coll.)

Atlanta, Georgia (L. Brown Coll.)

Jackson, Mississippi (Mrs.' J. V. Bogert Coll.)

Hattiesburg, Mississippi.

Charleston, South Carolina (V. T. Rogers Coll.)

Little Rock, Arkansas (W. J. Baerg Coll.)

Birmingham, Alabama (J. M. Lowrey Coll.)

Baton Rouge, Louisiana (Bishopp Coll.)

Key West, Florida (J. Y. Porter Coll.)

Orlando, Florida (W. W. Yothers Coll.)

Larkins, Florida (S. Graenicher Coll.)

San Diego, Florida.

Havana, Cuba (J. R. Taylor Coll.)

Ceará, Brazil (F. D. da Rocha. Coll.)

Campinas, Brazil (A. Hempel Coll.)

São Paulo, Brazil (Ad. Lutz Coll.)

Some of these localities have been reported by F. Knab (1916, Insecutor Inscitiæ Menstr., IV, pp. 3-4.)

Specimens at the Bureau of Animal Industry, U. S. Department of Agriculture:

Montgomery, Alabama (M. J. Myers Coll.)

Meridian, Mississippi. 

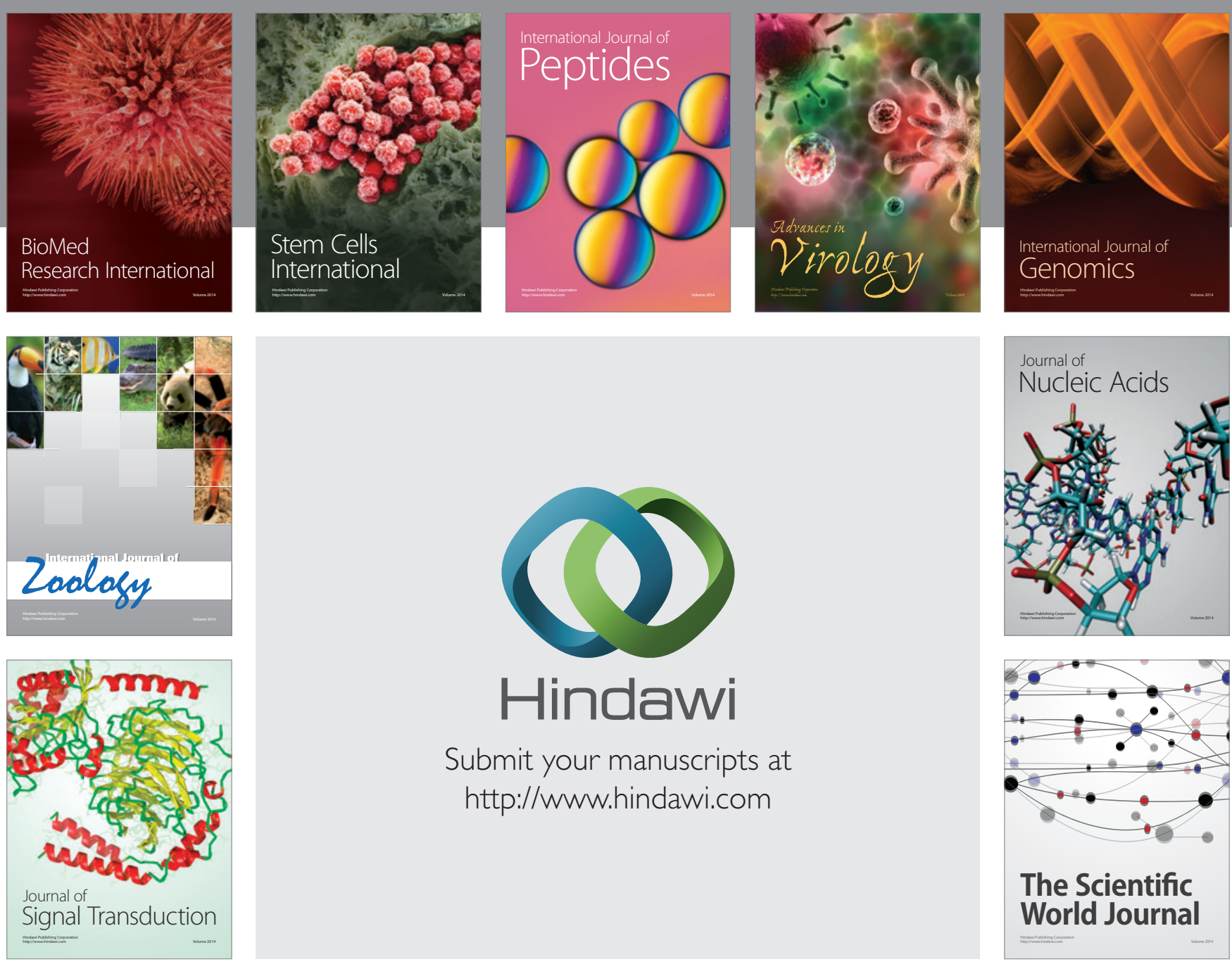

Submit your manuscripts at

http://www.hindawi.com
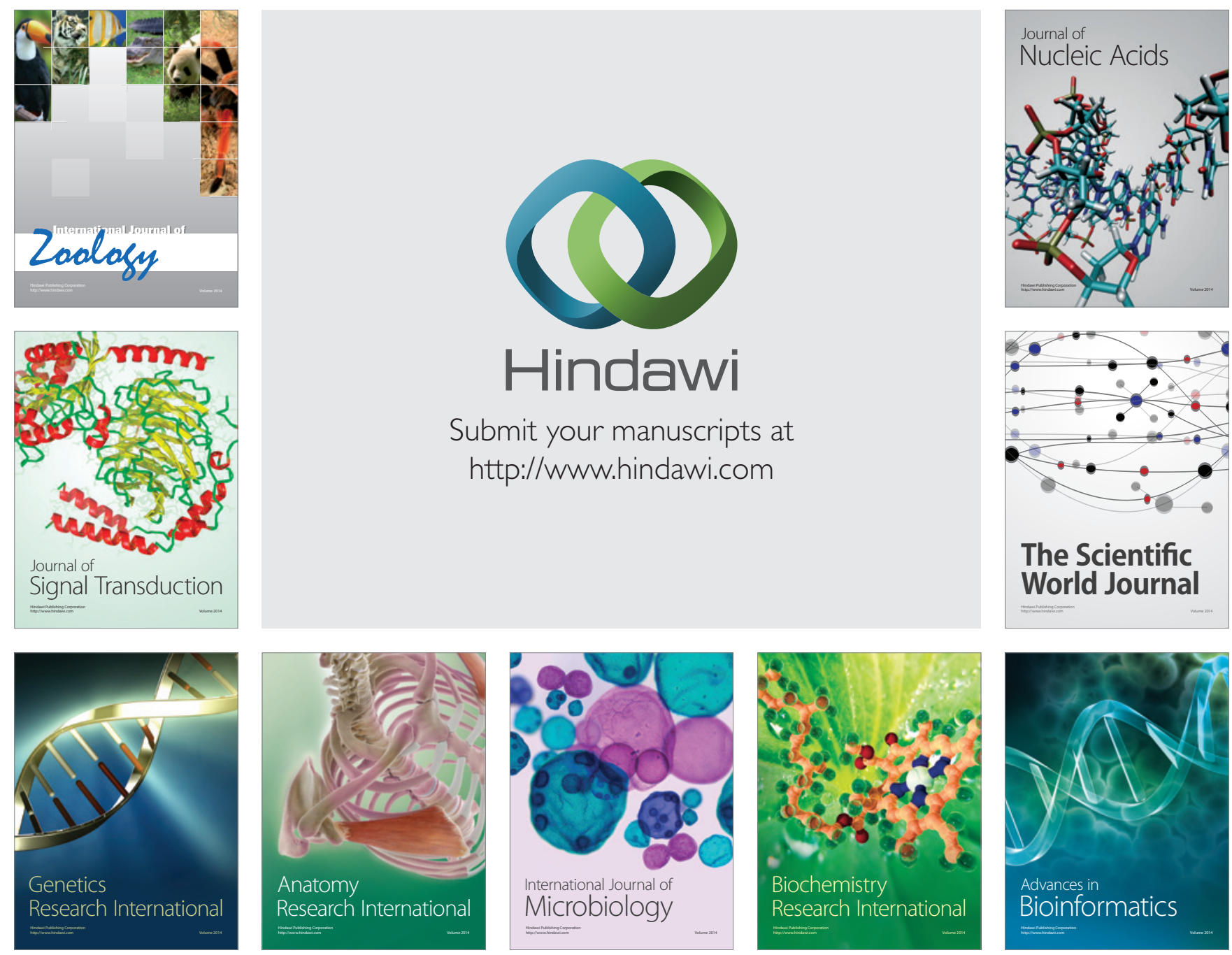

The Scientific World Journal
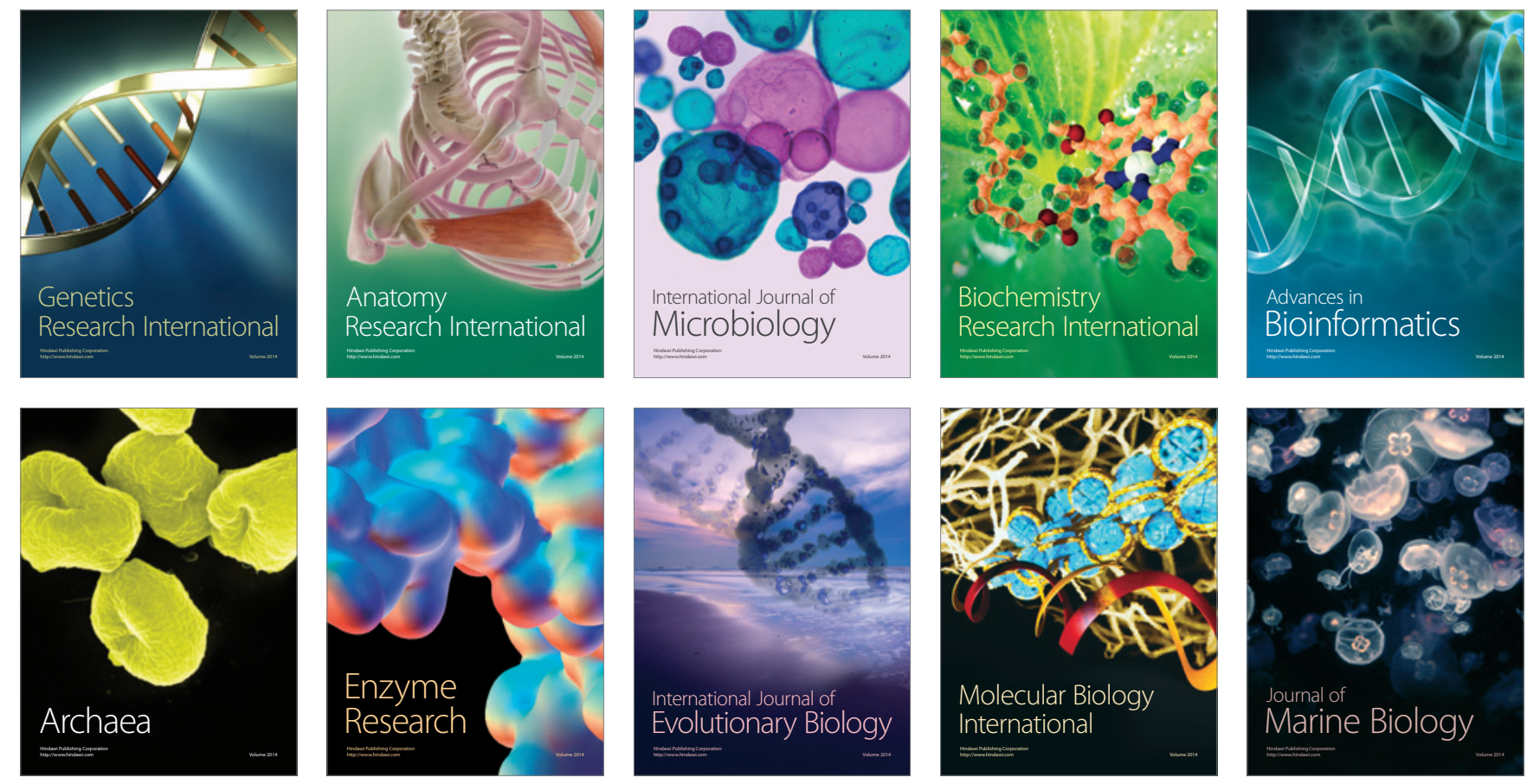